Prace Literackie LVIII

Wrocław 2018

https://doi.org/10.19195/0079-4767.58.27

DAWID SZKOŁA

ORCID: 0000-0001-6580-1288

Uniwersytet Wrocławski

\title{
Pomiędzy literaturą a dziennikarstwem. Uwagi wstępne o felietonach Josepha Rotha
}

Istnieją gatunki dziennikarskie i literackie, które nie poddają się łatwej charakterystyce. Mimo wielowiekowej tradycji i zadomowieniu się w książkach oraz gazetach nadal sprawiają trudności badaczom. Balansują na granicy tych dwóch dziedzin; uprawiane są przez twórców z drugiego obozu. Można śmiało powiedzieć, że bywają rebelianckimi tworami tekstowymi. O eseju Roma Syndyka pisze:

Esej jako niegatunek, antygatunek bywa więc postrzegany jako forma, które zadaniem jest ujawniać słabości systemowego rozumienia literatury i dowodzić, że wewnątrzliterackie zasady, granice i prawa zostały ustanowione arbitralnie, można więc podważać ich legitymizację ${ }^{1}$.

Nie inaczej jest z felietonem, który wręcz, jakby na przekór, przekracza wszelkie granice i nie pozwala się opisać. Żąda ciągle dodatkowego miejsca i zapośrednicza inne gatunki literackie oraz dziennikarskie. Za nic ma zasady i typologie, albowiem ciągle im się wymyka. Tworzy własne mozaiki i sieci, wplatając różne formy wypowiedzi we własną strukturę.

Francuskie słowo feuille — pisze Maria Wojtak — znaczy „liść”, a feuilleton oznacza „kartkę złożoną na czworo". Nazwę przypisywano początkowo wypowiedziom umieszczanym w dolnej kolumnie dziennika. Stanowiły one genologiczną mieszaninę, która dziś byłaby opatrzona nagłówkiem „Romaitości”. Z czasem terminem felieton zaczęto określać osobną formę publicystyki, zyskującą coraz większą komunikacyjną wyrazistość i grono wybitnych twórców ${ }^{2}$.

Przez cały XIX wiek felieton nabierał coraz to nowych kształtów (w Polsce chociażby tworzony wówczas był przez Cypriana Kamila Norwida, Jana Lama, Bolesława Prusa), jednak ciągle — nawet do dzisiaj — mógłby właśnie w języku polskim nosić nazwę rozmaitości. Co jest bowiem jego przedmiotem, o czym możemy przeczytać w felietonie? Śmiało należy powiedzieć, że o wszystkim.

${ }^{1}$ R. Syndyka, Nowoczesny esej. Studium historycznej świadomości gatunku, Kraków 2006, s. 69 .

${ }^{2}$ M. Wojtak, Gatunki prasowe, Lublin 2004, s. 203. 
Czy może być dziennikiem, monologiem, listem, impresją podróżną? Oczywiście. Drukowany jest w prasie, ale tworzony w dużej mierze przez pisarzy. Widać to szczególnie dobrze na polskim rynku od XX wieku aż po dzisiaj. Trudno nawet wybrać tylko kilku wybitnych twórców, aby nikogo ważnego nie ominąć. Jako czołowych felietonistów jednak na pewno wymienić można takie nazwiska jak: Tadeusz Boy-Żeleński, Antoni Słomiński, Stefan Wiechecki, Stefan Kisielewski, Jerzy Pilch, Krzysztof Varga, Andrzej Stasiuk. Jako ciekawostkę można dodać, że w tygodniku „Polityka” Sylwia Chutnik w duecie z Grażyną Plebanek drukują swoje felietony, więc nie muszą mieć one nawet jednego twórcy. Mogą być dziełem zbiorowym.

W ten sposób literatura uatrakcyjniła kolumny dziennikarskie, ale też „dzięki praktyce dziennikarskiej literatura wzbogaciła się o nowe formy — by wspomnieć obok krytyki literackiej — artykuł, komentarz, felieton, wywiad, reportaż”3. Felieton i proza artystyczna nie są od siebie wcale odległe. Jak esej często wplatany jest do beletrystyki, tak beletrystyka korzysta $z$ felietonu i na odwrót. Te dwa światy przenikają się na kartach książek i gazet codziennych, tygodników czy miesięczników. Świetnie ujął to Jerzy Pilch, mówiąc:

Ja tą samą jedną ręką piszę prozę i felietony, a nie jedną prozę, a drugą felieton. Pisząc, przeżywam tę samą psychodramę - tę samą udrękę i te same uniesienia. Mam do felietonu stosunek poważny, a nie bagatelizujący, jego lekka forma niech nikogo nie zmyli. To bardzo dowolny, ale i wyrazisty gatunek pisarski ${ }^{4}$.

Poza tym warto pamiętać, że autor Pod mocnym aniołem też wydał kilka książek ze swoimi felietonami, które cieszyły się podobną popularnością co jego powieści czy zbiory opowiadań. Podobnie ma się sprawa z Krzysztofem Vargą. Ich twórczość staje się paralelna. Felieton w ujęciu Pilcha okazuje się nie gatunkiem dziennikarskim, ale gatunkiem pisarskim. Publikowany jest bowiem w prasie, ale przecież często nie przez dziennikarzy, a twórców raczej związanych z szeroką rozumianą sztuką.

W dziennikarstwie często zwraca się uwagę na istnienie dwóch rodzajów dziennikarskich: informację i publicystykę.

Informacja ukazuje zjawiska, publicystyka łączy je i interpretuje. [...] Ale istnieją też podziały dziennikarstwa na trzy rodzaje. W trzecim zamyka się gatunki dziennikarsko-estetyczne czy dziennikarsko-literackie. I tak Zbigniew Mitzner wydziela trzeci rodzaj jako większe gatunki, zali-

${ }^{3}$ M. Hopfinger, Wspótczesne przemiany literatury a dziennikarstwo, [w:] Dziennikarstwo a literatura w XX i XXI wieku, red. K. Wolny-Zmorzyński, W. Furman, J. Snopek, Warszawa 2011, s. 22.

${ }^{4}$ J. Pilch, Komentarz do otaczającej doraźności, [w:] Biblia dziennikarstwa, red. A. Skworz, A. Niziołek, Kraków 2010, s. 634. 
czając do nich wywiad, reportaż i esej, najobszerniejsze, ale i najbardziej artystyczne, subiektywne, eksponujące autorskie ,ja"

Także w tym rozróżnieniu trudno znaleźć miejsce dla felietonu: nie jest on dostatecznie obszerną formą, aby znaleźć się wśród eseju czy reportażu, chociaż eksponuje autorskie ,ja” na każdym kroku, niemal w każdej linijce. Felietonowi bliżej do publicystyki, komentarza, recenzji, ale też z tej charakterystyki się wyłamuje. Komentuje on rzeczywistość, często może recenzować inne dzieła, ma charakter publicystyczny, ale zawsze jest dodatkowo czymś więcej. Jakby systemowe rozumienie do niego nie pasowało, a on sam cieszył się z własnego niedopasowania.

W rzeczywistości największy problem z felietonem (tak jak z esejem) jest taki, że stoi on na pograniczu dziennikarstwa i literatury. Bez prasy nie powstałby, ale bez swoich walorów literackich szybko popadłby w zapomnienie. Dziennikarstwo od zawsze wchodziło w relację z literaturą. „Relacje literatury i dziennikarstwa są stare jak... dziennikarstwo"6 — słusznie zauważa Jerzy Snopek. Stwierdzenie to rozwija Maryla Hopfinger, pisząc:

Gatunki wypowiedzi dziennikarskiej i literackiej podlegają nieustannym modyfikacjom, zmieniają się ich hierarchie i wewnętrzne reguły, pojawiają się nowe i więdną stare, ale istota i najgłębsze struktury, a także podstawowe formy ekspresji w obu praktykach komunikacyjnych, pozostają podobne lub wręcz takie same. [...] Generalnie jednak, powiedzieć wolno, że dziennikarstwo wywodzi się z tych samych źródeł, co literatura; jest jej młodszym rodzeństwem, jeśli nie potomkiem i nosi cechy rodzinne, genetyczne, widoczne okiem nawet pobieżnego i niezbyt dociekliwego obserwatora ${ }^{7}$.

Felieton potwierdza te zdania. Korzysta on z wszystkich zalet, jakie dają mu literatura i dziennikarstwo. Raz jego ciężar przenosi się na jedną, raz na drugą stronę. Podlegając zmianom, pozostaje dla czytelników zawsze jedną z najważniejszych części prasy współczesnej. Dostosowuje się do współczesności, będąc zarazem paradoksalnie w pewnym sensie taki sam. Nawet język, który jest zmienny, w felietonie zawsze pozostaje literacki. A przecież nie więdnie, wręcz przeciwnie. Niezauważenie się zmienia bowiem ze światem. Jest jego odbiciem, być może nawet wyrazistszym niż powieść, ponieważ nie ma tak długiego cyklu wydawniczego, ale ukazuje się niemal natychmiast od napisania. Dlatego może zostać uznane za współczesne zwierciadło przechadzające się pod ulicach. Rację ma zatem Bondkowska, gdy pisze:

W metaforycznym ujęciu Marka Pytasza paradygmatem felietonu jest „mowa świata”, z której autor wybiera to, co dla niego ważne, którą objaśnia na arbitralnie wybranym przykładzie, której narzuca komentarz i oceny. Felietonem sensu stricto jest w związku z tym tylko tekst będący świadectwem „mowy świata”, felietonem zaś sensu largo — każda wypowiedź identyfikowana przez

${ }^{5}$ K. Wolny-Zmorzyński, A. Kaliszewski, W. Furman, Gatunki dziennikarskie. Teoria, prakty$k a$, język, Warszawa 2009, s. 27-31.

${ }^{6}$ J. Snopek, Pisarstwo - dziennikarstwo. Wzajemne relacje. Uwagi wstęne, [w:] Dziennikarstwo a literatura..., s. 36.

${ }^{7}$ M. Hopfinger, op. cit., s. 26. 
czytelników albo autora jako felieton lub forma felietonowa, realizująca część cech podrzędnych gatunku ${ }^{8}$.

Metaforyczna „mowa świata” jest podawana czytelnikom przez felietonistę zgodnie z pewnymi założeniami literackimi. Autor wybiera sobie swobodnie temat i opisuje go, stosując różne zabiegi językowe. Felieton może przybierać kształt listu, dziennika, sprawozdania, jednak musi być identyfikowany przez autora i czytelników właśnie jako felieton. I tutaj natrafiamy na ważne stwierdzenie: co tak naprawdę można nazwać felietonem, jakie warunki musi on spełniać, aby zostać tak nazwany? Z pomocą przychodzi Maria Wojtak, która pisze:

Do grupy zewnętrznych wyznaczników gatunkowych felietonu zaliczono: stałe miejsce w piśmie, tytuł zbioru tekstów, cykliczność, różnorodne formy graficznego wyróżnienia tekstu lub jego fragmentów, sygnowanie wypowiedzi podpisem (często pseudonimem), niewielkie rozmiary wypowiedzi ${ }^{9}$.

Uwagi te wydają się oczywiste. Felieton powinien mieć swoje stałe miejsce w prasie, pewną nazwę cyklu, opierać się w dużej mierze na nazwisku autora (czy też jego pseudonimie) i mieć niewielkie rozmiary.

Podsumowując cechy typologiczne felietony, należy wymienić: niewielkie rozmiary; obecność narratora w pierwszej osobie; swobodny bądź synkretyczny styl, subiektywizm lub wręcz stronniczość; elementy ironii, satyry, paszkwilu, groteski; poufałość wobec odbiorcy; skłonność do puenty; dygresyjność; fragmentaryczność; używanie dialogu, monologu, cytatu, mistyfikacji, przesady, neologizmów, kalamburów, peryfraz, metafor, wulgaryzmów; cyklicznośćc ${ }^{10}$.

Ta typologia felietonu już w dużej mierze ukazuje jego synkretyczny i literacki charakter. Odróżnia go od komentarza czy artykułu pod wieloma względami, chociażby występowaniem monologu czy mistyfikacji. Równie ważna jest poufałość wobec odbiorcy i fakt jego braku zakotwiczenia w czasie, co sprawia, że wcale nie musi dotyczyć spraw bieżących. Może dotyczyć spraw historycznych, prozaicznych czy też istniejących tylko w głowie autora albo opierać się na cytacie z książki (lub zachowaniu bohatera dzieła literackiego). Ważna jest też jego tematyka, która wcale nie musi dotyczyć spraw ważnych dla odbiorców; tematem felietonu będzie w takim razie wyjście do sklepu, podróż, uczestniczenie w wydarzeniu sportowym, kulturalnym czy też w ogóle zapis przemyśleń autora w formie monologu albo strumienia świadomości. Nie jest wcale tak, że felieton musi traktować o jednej sprawie, lecz w formie bardziej eseistycznej omawiać pewne zagadnienia, przeskakując z tematu na temat, bawiąc się z czytelnikiem dygresjami, kalamburami, fragmentami różnych wypowiedzi. Felieton wymaga wtedy od czytelnika dodatkowej interpretacji i erudycji, sprawdza jego elokwencję, bez której możliwość interpretacji może okazać się niepełna lub szczątkowa. Komentarz jest subiektywnym przekazaniem pewnej informacji przez autora, ale

${ }^{8}$ M. Bondkowska, Struktura językowa felietonu dekady 1968-1978, Warszawa 2005, s. 36.

${ }^{9}$ M. Wojtak, op. cit., s. 204.

${ }^{10}$ K. Wolny-Zmorzyński, A. Kaliszewski, W. Furman, op. cit., s. 92. 
felieton domaga się od czytelnika dodatkowych umiejętności interpretacyjnych ${ }^{11}$. Sprawdza jego umiejętność wykrycia na przykład satyry czy ironii. Felieton zatem ma walory artystyczne, a nie tylko informacyjne czy publicystyczne. Bywa prowokacyjny, zatem wymaga od odbiorcy postawy polemicznej, jednak potrafi też służyć wyłącznie estetycznym wrażeniom i spełniać wymogi dobrze napisanej miniatury literackiej. Jeden felieton może spełniać wymóg publicystyczny, a inny być fikcją artystyczną, chociaż obydwie te strategie pisarskie mogą się mieszać w jednym tekście.

Układ treści w felietonie - pisze Bondkowska — może przybierać różne formy w zależności od poruszanego tematu, wykorzystywanych chwytów kompozycyjnych zaczerpniętych z gatunków pokrewnych, a także stopnia zbliżenia felietonu do któregoś z biegunów: publicystyczności (wtedy reguły kompozycyjne są ściślej określone i łatwiej przewidywalne) lub literackości (wówczas kompozycja tekstu jest luźniejsza, choć nigdy zupełnie dowolna) ${ }^{12}$.

W felietonie zatem - tej hybrydzie dziennikarstwa i literatury — dochodzi do zatarcia granicy między prawdą faktu a artystyczną fikcją. Dlatego nie bez powodu Magdalena Mateja nadała swojemu artykułowi o felietonie śródtytuł „Ambasador literackości na terytorium dziennikarstwa"13, a Anna Mlekodaj, w tym samym tomie, nazwała swój artykuł „Gawęda, felieton, opowiadanie? - dylematy genologiczne na pograniczu dyskursów" ${ }^{14}$. Mlekodaj w swoim artykule pisze:

W zakresie zaś sposobu ujęcia tematu felieton wykształcił cztery odmiany: fabularną, asocjacyjną, logiczno-dyskursywną oraz udramatyzowaną. Przyjmuje się bowiem, że może on być zbudowany według zasad przypominających te, które rządzą utworami fabularnymi, może przybrać postać swobodnych skojarzeń, może naśladować budowaną w myśl zasad logiki rozprawę, może wreszcie, na wzór dramatu, jedyną lub dominującą formą wypowiedzi uczynić dialog. Niejednorodność kryteriów podziału dopuszcza krzyżowanie się tych odmian w jednym tekście ${ }^{15}$.

W rzeczywistości zatem wychodzi na to, że felieton, przez możliwość krzyżowania się w nim wymienionych odmian, może przybierać przeróżne formy.

${ }^{11}$ Dlatego też Maria Wojtak (op. cit., s. 202) słusznie zauważa: „W odróżnieniu od takich gatunków jak komentarz czy reportaż informacja jest w felietonach przemycana w interpretacyjnym opakowaniu".

${ }^{12}$ M. Bondkowska, op. cit., s. 40.

${ }^{13}$ M. Matyja, Artyści — rzemieślnicy - chatturnicy. Poczet felietonistów polskich, [w:] Mistrzowie literatury czy dziennikarstwa, red. K. Wolny-Zmorzyński, W. Furman, J. Snopek, Warszawa 2011, s. 75 .

${ }^{14}$ A. Mlekodaj, Gawęda, felieton, opowiadanie? - dylematy genologiczne na pograniczu dyskursów, [w:] ibidem, s. 85.

${ }^{15}$ Ibidem, s. 87. Warto tutaj zacytować też Marię Wojtak (op. cit., s. 205): „Mówiąc o sposobie ujęcia tematu badacze zwracają uwagę na możliwość wystąpienia układów fabularnych, asocjacyjno-dygresyjnych bądź logiczno-dyskursywnych, a także posługiwanie się dialogiem. Eksponowana jest też niejednokrotnie swoboda wypowiedzi. Przypisuje się felietonistom »skłonność do puenty« i dbałość o sugestywny tytuł. [...] Dla felietonu charakterystyczna jest subiektywność czy wręcz stronniczość w sposobie ujmowania świata przedstawionego. »Podmiot manifestuje ostentacyjnie prywatny i przekorny stosunek do poruszanej problematyki« — stwierdza Maziarski. Inni badacze akcentują postawy polemiczne, prowokatorskie, ale też niejednokrotnie moralizatorskie". 
Sprawa dodatkowo się komplikuje, gdy felieton zapożycza od innych gatunków literackich.

Dostrzeżono mianowicie jego związki z różnorodnymi gatunkami piśmiennictwa użytkowego, wymieniając: list, dziennik, pamiętnik, przemówienie. Wśród gatunków, które, jak to określił Rams, felieton może sobą wypełniać, znalazły się ponadto: skecz, baśń i wiersz ${ }^{16}$.

Czyli inaczej rzecz ujmując: felieton może czerpać z niemal wszystkich form wypowiedzi ustnych i pisemnych. Dodatkowo te gatunki mogą w nim się krzyżować. Dlatego trzeba przypomnieć, jakie warunki jednak musi spełniać felieton, by zostać tak nazwany: stałe miejsce w porządku pisma i cykliczność, niewielkie rozmiary, sygnowanie wypowiedzi podpisem (może być pseudonimem, ale jednak autor felietonu nigdy nie jest anonimowy), wyróżnienie graficzne. Należy też wspomnieć, że felieton ma strukturę kompozycyjnie zamkniętą, ma puentę. Te wyznaczniki zewnętrzne wydają się oczywiste. Wszystko właśnie komplikuje się, gdy badamy wyznaczniki wewnętrzne felietonu. Czerpie on bowiem z pola literackiego jak żaden inny gatunek dziennikarski. Dlatego tak ważna jest postać autora tekstu, który możemy uznać za felieton. To on zaznacza swoim imieniem i nazwiskiem (bądź pseudonimem), że tworzy felieton. Na przykład gdy ma cotygodniową rubrykę w dzienniku. Może być znanym pisarzem, politykiem, celebrytą. „Felietonista, na ogół człowiek o znanym nazwisku i twarzy, wyraźnie akcentując swój punkt widzenia, formułuje polemiczne, a czasami wręcz kontrowersyjne, sądy"17. Jak już było wcześniej zaznaczone, może on do tego używać i zarazem zapożyczać wielu gatunków literackich. Nie musi przy tym wcale pisać akcentować własnych poglądów, lecz wprowadzać czytelnika w swoistą grę interpretacyjną. Bynajmniej nie potrzebuje też opisywać wydarzeń prawdziwych. Fikcja literacka sprawdza się jako

składnik o charakterze intelektualnym i twórczym; dzięki niemu nadawca może w celach tendencyjnych, perswazyjnych lub artystycznych kondensować fakty i kreować świat, który w odczuciu odbiorcy pozostaje autentyczny. Fikcja artystyczna, będąca zespoleniem elementów zmyślonych oraz faktów, pozwala felietoniście akcentować prawdziwość przedstawionej problematyki w sytuacjach przejaskrawionych, umożliwia analizowanie stanów psychicznych bohatera itd. ${ }^{18}$

Autor felietonu może posiłkować się zmyśleniem i fikcją, jeśli chce ukazać w sposób jak najbardziej wartościowy wybrany przez siebie temat. Jest to niemożliwe w żadnym tekście dziennikarskim, ale właśnie felietoniście wolno więcej. Przez grę, którą toczy z czytelnikami, pozwala on sobie na zabawę z treścią. Zdarza mu się w sposób groteskowy pisać o sprawach poważnych i na odwrót. Wcale też nie musi przedstawiać własnych poglądów. Wtedy granica między

\footnotetext{
16 Ibidem, s. 216.

17 A. Mlekodaj, op. cit., s. 86.

${ }^{18}$ M. Matyja, op. cit., s. 76.
} 
tekstem dziennikarskim a literackim podlega całkowitemu zatarciu. Już nie można powiedzieć, po której stronie stoi autor. Zwłaszcza jeżeli używa pseudonimu, w ten sposób próbując pokazać odczucia kogoś innego.

Istotny „,identyfikator” felietonowej literackości stanowi postać narratora, a konkretnie sposób konstruowania tego elementu struktury. Zaznaczaniu dystansu między autorem a narratorem służy m.in. mechanizm zastępowania nazwiska pseudonimem. W artykule publicystycznym lub w eseju jednoznacznie utożsamia się narratora $\mathrm{z}$ autorem tekstu, $\mathrm{w}$ felietonie mamy natomiast subtelną grę między ,ja” i „nie ja”; podmiot narracji to odcina się od rzeczywistego autora, to znów identyfikuje się z nim i w jego imieniu wygłasza sądy mające cechy rzetelnej wypowiedzi publicystycznej ${ }^{19}$.

Bez wątpienia za autora, który łączył literaturę z felietonem, uchodzi Joseph Roth. Zanim wydał swoje najsłynniejsze powieści, jak Hiob czy Marsz Radetzky'ego, był wziętym felietonistą i od pracy dziennikarskiej rozpoczynał swoją wielką karierę literacką, która rozbłysła w dwudziestoleciu międzywojennym w całej Europie, a gasła tym bardziej, im większa była władza nazistów. Jednak od końca pierwszej wojny światowej Roth drukował w takich czasopismach jak: „Der Neue Tag”, „Vorwats”, „Frankfurter Zeitung” i „Prager Zeitung”. O jego powieściach napisano wiele, ale o felietonach prawie nic. Jakby były „gorsze", napisane innym językiem czy nie pasowały do twórczości tego wielkiego stylisty. Słusznie zatem uwagę zwraca Michael Frank, pisząc:

Powieściopisarz i nowelista Roth, wielki talent okresu międzywojennego, jest wszechobecny; felietonista Roth uchodzi wprawdzie, jeżeli w ogóle jest znany, za znakomitość, ale jedynie w charakterze miłego zjawiska towarzyszącego. Napisano legion cały naukowych rozpraw, uwierzytelniających renomę jego szesnastu powieści, niewiele natomiast na temat jego felietonów: literat przesłonił oczywiście dziennikarza ${ }^{20}$.

W Polsce natomiast od kilku lat wydawnictwo Austeria wydaje jego zbiory felietonów. Wśród nich są: Wiedeńskie znaki czasu. Felietony z lat 1915-191921, Proza podróżna ${ }^{22}$, Listy z Polski ${ }^{23}$, Podróż do Rosji ${ }^{24}$ czy Oblicza czasu. Felietony z roku $1920^{25}$. Ukazują one pokaźny, choć oczywiście niepełny, dorobek felie-

19 Ibidem, s. 75.

${ }^{20}$ M. Frank, Obiektywizm jest świństwem, [w:] Samotny wizjoner. Joseph Roth we wspomnieniach przyjaciół, esejach krytycznych i artykułach prasowych, przeł. P. Krzak, red. E. Jogałła, Kraków-Budapeszt 2013, s. 352.

${ }^{21}$ J. Roth, Wiedeńskie znaki czasu. Felietony z lat 1915-1919, przeł. M. Łukasiak-Zięba, Kraków-Budapeszt 2016.

22 J. Roth, Proza podróżna, przeł. M. Łukasiewicz, Kraków-Budapeszt-Syrakuzy 2018.

23 J. Roth, Listy z Polski, przeł. M. Łukasiewicz, Kraków-Budapeszt-Syrakuzy 2018.

24 J. Roth, Podróż do Rosji, przeł. M. Łukasiewicz, Kraków-Budapeszt-Syrakuzy 2019.

25 J. Roth, Oblicza czasu. Felietony z roku 1920, Kraków-Budapeszt-Syrakuzy 2019. 
tonistyczny Rotha przetłumaczony na język polski ${ }^{26}$. Felietony te drukowane były w wielu najważniejszych czasopismach niemieckojęzycznych. Poświadczają przy tym, że „Roth jest mistrzem krótkiej formy literackiej, eseju, a mówiąc językiem dziennikarskim — felietonu"27. No właśnie — krótkiej formy literackiej, eseju czy felietonu? Roth pisał bowiem z gracją na wiele tematów, często jego teksty dziennikarskie przybierały różne formy i stylizacje językowe. Jednak uwzględniwszy wskazane tu wyznaczniki zewnętrzne felietonów, czyli stałą rubrykę, cykliczność, sygnowanie wypowiedzi podpisem czy niewielką formę, należy uznać twórczość dziennikarską Rotha za felietonistykę. Roth często sygnował swoje felietony pseudonimem, publikował je w czasopismach. Szczególnie owocna była współpraca z „Frankfurter Zeitung” rozpoczęta w 1923 roku. Wtedy to Roth stał się też jednym z najlepiej opłacanych dziennikarzy w Niemczech ${ }^{28}$.

Wówczas, w połowie lat dwudziestych, Joseph Roth — pisze Reinhard Baumgart — znajdował się jeszcze na początku swojej literackiej drogi. Natomiast jego dziennikarska kariera już od dłuższego czasu sięgała apogeum. Rozpoczął ją w Wiedniu, pośród kolegów tak renomowanych jak Alfred Polgar, Anton Kuh czy Egon Erwin Kisch, w stosunku do których, jako felietonista, reporter i autor polemik, zachowywał wyczuwalną bliskość, ale też wyraźny dystans. Z jakąż pewnością wyraża swój punkt widzenia już w pierwszych artykułach, którym nadaje niepowtarzalny ton. Styl, w którym formułuje wściekłość, smutek i nadzieję jest uderzająco osobisty ${ }^{29}$.

W tych zdaniach też widzimy pewien wyznacznik felietonistyki - nie tylko — Rotha. Właśnie ten osobisty ton, połączony z nazwiskiem autora, przyciągał wielu czytelników.

Autor Hioba pisał o kryzysie powojennym, pokrzywdzonych ludziach, filmie, literaturze i dziełach sztuki, opisywał swoje podróże po Rosji, Galicji czy Austrii. Opisywał w nich to, co widział, i to, co czuł. Właśnie te odczucia sprawiły, że zdobył tak wielką popularność. Ten niemieckojęzyczny Żyd z polskim paszportem, urodzony w dalekich Brodach i tęskniący za cesarstwem Franciszka Józefa, był szczególnie nastawiony na indywidualne spojrzenie.

Teksty, pisane z zamierzeniem dotarcia do prawdy, uważa za przestępcze. Godne respektu czytelnika jest dla niego jedynie takie patrzenie na rzeczywistość, w którym rozpoznawalna jest droga sprawozdawcy lub interpretatora poprzez jego ,ja" - widzenie rzeczy, które ewidentnie nosi w sobie piętno osobistego postrzegania świata i wartości. Indywidualne spojrzenie uszlachetnia i nobilituje, ale równocześnie ujawnia zewnętrzność wytworu sztuki w relacji do rzeczywistości ${ }^{30}$.

Właśnie owo ,ja” narratora w felietonie jest bardzo ważnym wyznacznikiem tego gatunku dziennikarskiego. Umiejętność widzenia rzeczy i wydarzeń po swojemu jest z kolei prawdopodobnie najważniejszą cechą felietonisty. Przy tym

${ }^{26}$ Felietony te zostały przetłumaczone i pochodzą z: J. Roth, Das journalistische Werk. 1915 1923, Köln 1989; idem, Das journalistische Werk. 1924-1928, Köln 1990. W Listach z Polski tylko jeden felieton pochodzi z lat późniejszych: idem, Das journalistische Werk. 1929-1939, Köln 1991.

27 J.T. Gross, Rosyjska lokomotywa nie gwiżdze, ale wyje..., [w:] J. Roth, Podróż do Rosji, s. 8.

${ }^{28}$ R. Baumgart, Trzy spojrzenia, [w:] Samotny wizjoner, s. 241.

${ }^{29}$ Ibidem.

${ }^{30}$ M. Frank, op. cit., s. 354. 
wszystkim teksty dziennikarskie Rotha dodatkowo objawiają się czytelnikowi literackim językiem, który zwiastował przyszłego prozaika. W tych felietonach nie brakuje ironii ani satyry. Razem tworzą — jak Listy z Polski czy Podróż do Rosji - zwartą całość, ale czytane pojedynczo okazują się wybitnymi miniaturami, w których jest sprawozdana cała opowieść, anegdota, zobaczone miejsce czy dzieło sztuki.

W felietonach Rotha, które zostały przetłumaczone na język polski, znajdziemy stałe, główne, motywy.

Motyw granic międzypaństwowych, który Roth poruszał bardzo często. Szczególnie dużo miejsca poświęcił on temu zagadnieniu w Wiedeńskich znakach czasu, ale też Listach z Polski czy Podróżach po Rosji. Roth pisał, że granice $\mathrm{z}$ dnia na dzień mocniej dzielą ludzi i ich przekroczenie jest coraz bardziej związane z biurokracją. Ich symbolem stały się paszporty, które przypisują człowieka do danego obywatelstwa i nie zakładają jego różnorodności. „Państwo i kontrola graniczna sprzymierzyły się: chcą mnie zniszczyć” 31 . W innym felietonie dodawał, że ,granice polityczne także przestały już być punktami, kreskami, liniami, i przeobraziły się w pasmo szykan, udręki, pasji, Golgot, dróg krzyżowych, jednym słowem: kontrole graniczne..." ${ }^{32}$. W takim wypadku granice międzypaństwowe stawały się nie tylko miejscem dzielącym ludzi, biurokratyczną maszyną niszczącą indywidualność, lecz także zwykłym miejscem katorgi. Ich zadaniem była kontrola i przypisywanie człowieka do danej grupy, z czym Roth się nigdy nie godził. Ten obywatel wieloetnicznego cesarstwa, urodzony w miejscowości przygranicznej, wiedział, że kawałek papieru z wpisanym miejscem urodzenia nikogo nie może nikogo scharakteryzować.

Motyw hotelu w felietonach Rotha, który po pierwszej wojnie światowej nie miał stałego miejsca zamieszkania, powracał równie często. Przez większość swojego dorosłego życia mieszkał w hotelach, o których pisał jak o własnym domu. Ich pracowników natomiast traktował jak własną rodzinę. Hotel był również miejscem wygnania ludzi podobnych do niego: ludzi bez ojczyzny, sierot po wieloetnicznym cesarstwie Franciszka Józefa. W hotelu spotykają się: „ludzie wyrwani z ciasnoty lokalnych więzi, uwolnieni od otępienia patriotyzmu, urlopowani od narodowej buty i przynajmniej wydają się tym, czym zawsze powinni być: dziećmi tego świata"33. Właśnie ci ludzie — podróżnicy, bez stałego miejsca zamieszkania, włóczędzy i sieroty po przedwojennym świecie — byli najbliżsi autorowi Hioba. To oni tworzyli jego rodzinę. Nie należeli do niej wyłącznie goście hotelu, ale również jego pracownicy. Byli jego najbliższą rodziną i to im poświęcił wiele swoich felietonów. Przypominali mu bowiem podobnych do niego kulturowych odmieńców, ludzi, którzy nie potrafili scharakteryzować swojej przynależności.

31 J. Roth, Wiedeńskie znaki czasu, s. 250.

32 Ibidem, s. 177.

33 J. Roth, Proza podróżna, s. 98. 
Równie ważny wydaje się motyw Galicji jako przestrzeni wielokulturowej i wieloetnicznej upadłego państwa Franciszka Józefa, jak również później terenów należących do II Rzeczypospolitej. Roth był idealnym mieszkańcem kraju koronnego Królestwa Galicji i Lodomerii. Urodził się w typowym sztetlu (żydowskim miasteczku), w którym kontakt mieli z sobą Żydzi, Polacy, Ukraińcy, Rosjanie, Niemcy, Austriacy i inne narodowości zamieszkujące te tereny. Widział różnice między tymi nacjami, ale też ich współżycie w tej przestrzeni. Brody leżały na skraju Galicji, między caratem i cesarstwem, tym samym dodatkowo były nacechowane wielokulturowo. Roth demitologizował Galicję i jej nie oceniał. Widział, jak wielki wpływ miała na cesarstwo, ale też dostrzegał tamtejszą biedę. Pisał, że Galicja ma:

[w] Europie Zachodniej złą sławę. [...] Trudno jest żyć. Galicja ma ponad osiem milionów mieszkańców do wyżywienia. Ziemia jest bogata, ludność biedna. Są to chłopi, handlarze, drobni rzemieślnicy, urzędnicy, żołnierze, oficerowie, kupcy, bankowcy, właściciele ziemscy. Handlarzy, urzędników, żołnierzy, oficerów jest za dużo. Wszyscy żyją właściwie z jednej klasy produktywnej: chłopów ${ }^{34}$.

Jednak zauważał, że nie była ona wcale odizolowana od reszty Europy, lecz wręcz przeciwnie - tworzyła jej część. Była terenem przygranicznym, łączącym Wschód i Zachód, wydawała wyjątkowych ludzi, do których przecież sam Roth się zaliczał. Ludzi będących mieszanką cech i tradycji ludów ją zamieszkujących. Ludzi, którzy przyczyniali się do wzrastania kultury oraz nauki europejskiej i światowej, jak Szmuel Agnon, Józef Dietl, Leopold von Sacher-Masoch i przecież wielu innych, dla których nie starczyłoby miejsca w skromnie objętościowym artykule.

Roth powracał często w swoich felietonach do czasów Cesarstwa Austro-Węgierskiego, który to temat był głównym motywem jego późniejszych książek (szczególnie widać to w Marszu Radetzky'ego). Tęsknota za dobrymi starymi czasami widoczna już jest $\mathrm{w}$ jego pierwszych tekstach dziennikarskich i potęgowała się w następnych latach. Wraz z upadkiem państwa Franciszka Józefa nastąpił rozpad starego porządku, który gwarantował ludziom wiele swobód. Natomiast wraz z powstawaniem państw narodowych zaczęły tworzyć się granice, nowe prawa i potęgowała się biurokracja. Roth na zawsze utracił państwo, w którym przyszedł na świat, tracąc $w$ ten sposób jakby czas dzieciństwa.

Należy również wspomnieć, że Roth poświęcił w swojej felietonistyce wiele miejsca innym krajom i miastom. Pisał bowiem o Rosji, Austrii, Francji, pisał o Wiedniu, Berlinie, Łodzi, ale też mniejszych miasteczkach. Był niestrudzonym podróżnikiem, który przemierzał nie tylko historyczne i literackie granice, lecz także pisał teksty dziennikarskie o tych miejscach. Jednak ważniejszym motywem, który często powraca w jego felietonach, jest jego natura flâneura. „Jestem spacerowiczem" 35 - pisał o sobie już w 1921 roku. Motyw spacerów po miastach był jednym z ważniejszych motów felietonów Rotha. Wychwytywał on najskryt-

\footnotetext{
34 J. Roth, Listy z Polski, s. 27-28.

35 J. Roth, Proza podróżna, s. 22.
} 
sze tajemnice ulic i napotkanych ludzi, opisywał najdrobniejsze szczegóły z ich życia i codziennych zachowań. Przy tym zachowywał swoje poczucie wędrownej bezdomności, która przejawiała się tym, że dzięki poczuciu wyobcowania mógł widzieć więcej niż ludzie zadomowieni w danej przestrzeni. „Co za rozkosz być obcym!"36 — pisał. Samotność, ale też jego galicyjska niespieszność sprawiały, że nie przechodził obok wielu spraw obojętny i tworzyły one temat jego felietonów pisanych „z ulicy”.

Jego teksty o ulicy bez wątpienia można połączyć z motywem ludzi żyjących poza nawiasem społeczeństwa. Te pełne czułości felietony być może okazały się zarazem również najważniejszymi i ponadczasowymi tekstami dziennikarskimi Rotha. Szczególnie interesujące okazały się te felietony, w których poświęcił on wiele miejsca ofiarom pierwszej wojny światowej: kalekom, bezdomnym, zdemobilizowanym żołnierzom. Wiele miejsca zajmują w jego felietonach $\mathrm{z}$ roku 1919, ale też najdobitniej widać to w tekście z 1924 roku pod tytułem Kaleki ${ }^{37}$. Opisał on w nim pogrzeb Jana Kosa, polskiego żołnierza, który po pierwszej wojnie światowej popełnił samobójstwo. Na jego pogrzebie we Lwowie w 1924 roku zjawili się wszyscy inwalidzi z miasta. „Ci, którzy mogli kuśtykać, kuśtykali, ci, którzy mogli się czołgać, czołgali się, a ci, którzy wcale nie mogli się poruszać, leżeli na wielkim wozie ciężarowym" ${ }^{38}$. Jest to bez wątpienia jeden z najlepszych felietonów Rotha, w którym widać całą jego wrażliwość, ale też złość na to, jak traktuje się opuszczonych przez państwo inwalidów wojennych, znikąd niemogących liczyć na pomoc. Weterani byli w felietonistyce Rotha ważnym budulcem, widział w nich bowiem ofiary złego losu, polityki i polityków, którzy rzucili ich $\mathrm{z}$ ochotą na fronty pierwszej wojny światowej.

Równie ważny wydaje się motyw zwykłych ludzi dotkniętych różnymi rodzajami nieszczęść. Roth napisał przejmujące felietony o szpitalu dla psychicznie chorych, rozlanym mleku w tramwaju, gdy był to towar deficytowy, o tym, że brakuje chleba, czy o osobach, które aby przetrwać, próbowały zarobić, żebrząc czy sprzedając nikomu niepotrzebne rzeczy. Wtedy absolutnie objawiał się dziennikarski talent autora Hioba. W kilku słowach potrafił on przedstawić tragiczną sytuację najbiedniejszych i porzuconych, bo sam często w przeszłości do tej grupy należał. Ludzie ulicy stanowili dla niego jeden z najważniejszych temat, los zwykłego człowieka był jego głównym motywem. „Tak, także oni, te karykatury Boga, mają serca i mózgi oraz bagaż doświadczeń i przeżyć przekute na ich los. Warto więc wysłuchać, co mają do powiedzenia"39 — pisał w 1919 roku. Temat ten wielokrotnie powracał w jego tekstach dziennikarskich. Roth zawsze stał po stronie tych, którzy zostali porzuceni przez Boga i innych ludzi, wszystkich tych, o których nikt nie pamiętał, wszystkich tych, od których inni odwracali wzrok.

\footnotetext{
${ }^{36}$ Ibidem, s. 27.

37 J. Roth, Listy z Polski, s. 39-42.

38 Ibidem, s. 40.

${ }^{39}$ J. Roth, Wiedeńskie znaki czasu, s. 106.
} 
Ludzie poturbowani przez los byli mu bliscy, widział w nich ofiary mizerii i głupoty polityki, polityków, idei i ówczesnego kapitalizmu.

Oczywiście Roth pisał także wiele o wojnie, nacjonalizmie, portretował miasta i ludzi, pisał o kinie, plakatach, oknach. Ten zbiór głównych motywów na pewno jest niepełny, albowiem o samych jego podróżach można wiele napisać. Jego felietonistyka zahaczała o wiele tematów, dzięki temu należy pamiętać, że nie była wcale uboższa literacko od napisanych później wielkich powieści. Stanowiła dla nich początek, kiedy to przyszły autor Hioba wytwarzał swój styl i poruszał motywy, które odnajdziemy w jego twórczości beletrystycznej. Dlatego nie powinno się twórczości dziennikarskiej Rotha umniejszać, ale widzieć w niej ważną część twórczości pisarza pochodzącego z Brodów. W jego felietonach, jak słusznie zauważył Adam Lipszyc: „Widzimy [...], jak przyszły pisarz ostrzy sobie piór — na świat i na nas wszystkich, którzy będziemy go czytali" ${ }^{40}$.

$$
* * *
$$

Roth był przedstawicielem rodu felietonistów, których los obdarzył wielką empatią. Hermann Kesten pisze, że autor Hioba jest „mistrzem felietonów. Komponował je ze skrawków własnego życia, a one z kolei wpływały na jego życie" 41 . Ale komponował je też ze skrawków życia innych. Właśnie wtedy ukazywał się czytelnikom jego kunszt. Roth bowiem ,jest - pisał Kesten — specjalistą od ludzi straconych. Interesuje go upadek jednostek zupełnie zwykłych, ich dyskretna tragiczność. Jest łowcą ludzi, ale tropi przede wszystkich nieszczęśliwych i upadających" ${ }^{42}$. Brało się to stąd, że sam do nich należał. Był galicyjskim Żydem, który nie raz poznał, czym jest bieda i wykluczenie. I taki też był „felieton galicyjski”. Pisze o tym Krzysztof Czyżewski takimi słowami:

Felieton galicyjski, od Franzosa poczynając, podróżował na linii kolejowej między Lwowem a Czerniowcami, zatrzymując się na każdej najmniejszej stacji; docierał na najdalsze rubieże, nawet tam, gdzie zwykło się mówić ,przepadł w Brodach”; nie stronił od ciętego humoru; zawsze stawał po stronie słabych i wykluczonych; posługiwał się cudowną receptą monarchii habsburskiej concordia discors (zgodność rozbieżności), formował Austriaka jako „człowieka ponadnarodowego” i pamiętał, ,że istotę Austrii stanowią jej peryferie, a nie centrum"; szanował galicyjskie miasteczko, które nie zapewnia wygody, ale „nawet filistrów zmienia w osobliwości. Sprzyja ewolucji w kierunku dziwactwa"43.

Zgodność w rozbieżności, tolerancja dla innych, ale nie głupoty, austriackie poczucie niespieszności i bardziej swobodnego podejścia do życia niż niemieckie, to wszystko sprawiało, że felietonistyka Rotha nie miała sobie równych. Dlatego potrafił tak przejmująco pisać o rozlanym mleku w tramwaju, lwow-

\footnotetext{
${ }^{40}$ A. Lipszyc, Listy z Schildy, [w:] J. Roth, Oblicza czasu, s. 11.

${ }^{41}$ H. Kesten, Joseph Roth, [w:] Samotny wizjoner, s. 185.

42 Ibidem, s. 201.

${ }^{43}$ K. Czyżewski, Wstęp, [w:] J. Roth, Listy z Polski, s. 15-16.
} 
skich ulicach czy rosyjskich przejściach granicznych. Wszędzie widział więcej, więcej czuł i pisał lepiej niż inni. Jego teksty dziennikarskie bywały momentami sentymentalne, ale miały również siłę przekazu, niezgodę na biedę i głupotę. To sprawiło, że Roth autor powieści nie powinien nam przesłonić felietonisty Rotha.

\title{
Bibliografia
}

Biblia dziennikarstwa, red. A. Skworz, A. Niziołek, Kraków 2010.

Bondkowska, Struktura językowa felietonu dekady 1968-1978, Warszawa 2005.

Dziennikarstwo a literatura w XX i XXI wieku, red. K. Wolny-Zmorzyński, W. Furman, J. Snopek, Warszawa 2011.

Furman W., Kaliszewski A., Wolny-Zmorzyński A., Gatunki dziennikarskie. Teoria, praktyka, język, Warszawa 2009.

Mistrzowie literatury czy dziennikarstwa, red. K. Wolny-Zmorzyński, W. Furman, J. Snopek, Warszawa 2011.

Roth J., Das journalistische Werk. 1915-1923, Köln 1989.

Roth J., Das journalistische Werk. 1924-1928, Köln 1990.

Roth J., Das journalistische Werk. 1929-1939, Köln 1991.

Roth J., Listy z Polski, przeł. M. Łukasiewicz, Kraków-Budapeszt-Syrakuzy 2018.

Roth J., Oblicza czasu. Felietony z roku 1920, Kraków-Budapeszt-Syrakuzy 2019.

Roth J., Podróż do Rosji, przeł. M. Łukasiewicz, Kraków-Budapeszt-Syrakuzy 2019.

Roth J., Proza podróżna, przeł. M. Łukasiewicz, Kraków-Budapeszt-Syrakuzy 2018.

Roth J., Wiedeńskie znaki czasu. Felietony z lat 1915-1919, przeł. M. Łukasiak-Zięba, Kraków-Budapeszt 2016.

Samotny wizjoner. Joseph Roth we wspomnieniach przyjaciót, esejach krytycznych i artykułach prasowych, przeł. P. Krzak, red. E. Jogałła, Kraków-Budapeszt 2013.

Syndyka R., Nowoczesny esej. Studium historycznej świadomości gatunku, Kraków 2006.

Wojtak M., Gatunki prasowe, Lublin 2004.

\section{Between literature and journalism. Introduction to the feuilletons of Joseph Roth}

\author{
Summary
}

The article describes the borderline between literature and journalism via the example of a newspaper feuilleton. I present the feuilleton as a kind of text that is difficult to define. Afeuilleton has much in common with journalism and literature, it also does not have one obligatory form or style of language. It can be similar to a letter, travel text, or monologue. Authors of feuilletons are often well-known writers who combine literature and journalism. In the article I use the example of Joseph Roth.

Keywords: Feuilleton, literature, journalism, Joseph Roth, press 